\title{
How Private Higher Education Institutions In Indonesia Changed Their Marketing Mix Amidst The Covid-19 Pandemic
}

\author{
Andamar Pradipta ${ }^{*}$ \\ 'Indonesia International Institute for Life Sciences, Jakarta, Indonesia \\ 1*andamar.pradipta@i3l.ac.id
}

\begin{tabular}{l}
\hline Article Info \\
\hline Article history \\
Received July 19, 2021 \\
Revised August 19, 2021 \\
Accepted November 2, 2021 \\
\hline
\end{tabular}

Keywords: Demands; COVID-19 pandemic; Higher education institutions; Marketing mix; Parents

\begin{abstract}
The COVID-19 pandemic has significantly affected industries to amass consumers, with the education industry not being an exception. For-profit higher education institutions (HEls) in Indonesia were forced to rethink their marketing strategies amidst COVID-19 restrictions and a changing economy. Five private HEls from four different cities in Indonesia have been the subjects of this study, focusing on how parents' demands and the pandemic drove changes in these HEls' 7P marketing mix. In-depth interviews were conducted with representatives of these HEls' marketing teams. It was found that three of the seven Ps in the HEls, as mentioned above, ' marketing mix, were changed (price, promotion, and process). It was concluded that Indonesian HEls bear a distinct producer-consumer relationship that hinders patrons from making demands as freely as they would with other types of services. Future research should then look into this newly-discovered producerconsumer dynamic in other levels of education.
\end{abstract}

\section{INTRODUCTION}

For-profit higher education institutions (HEls), which have fully evolved into one specific type of enterprise, are subject to the demands created by the changes in the environment (Bapat \& Gankar, 2019). In 2020, universities worldwide were forced to adapt to the thenemerging COVID-19 pandemic and resort to digital learning platforms (Jandrić, 2020). Until the writing of this paper, the Indonesian government's ban on face-to-face classroom learning would remain. HEls across the country have been utilizing different online learning strategies to run their classes. Most students whose first year at the university was in 2020, as a result, had not had the opportunity to step foot on their campus grounds.

Education marketing, in regards to HEls, has placed its focus on the 'recruitment-oriented' endeavors, which would consist of "open days, advertising campaigns and alumni events rather than considerations, such as the marketing orientation, market fit and commercial relevance of modules and degree programs" (Durkin et al., 2016, p. 355). The changes in social activities during the COVID-19 pandemic would see alterations being made in the methods of HEls marketing and the services that are being marketed, as all learning activities must be done remotely through online platforms. Inevitably, the pandemic would eventually affect the marketing mix employed by the marketing teams from different HEls. 
This paper focuses on the alterations made towards the 7P marketing mix of different private HEls in Indonesia, as they are known to use their marketing teams for marketing their services, as opposed to their public counterparts. The 7P marketing mix has been used multiple times in the discussions on HEls and their marketing strategies, as demonstrated by Bapat and Gankar (2019) and Tahir et al. (2017). As there is an abundance of contributing factors that influence the choice of university amongst prospective students (Maniu \& Maniu, 2014), HEls are required to employ different strategies to market their services, especially during a worldwide pandemic that can halt many on-campus activities for a long time. The alterations to the 7P marketing mix of the sample HEls studied in this research will show how much HEls have adapted to the education market's new demands during the COVID-19 pandemic.

\section{LITERATURE REVIEW}

\subsection{Education Marketing}

Yang (2016) defined the concept of 'education marketing' as the "application of marketing management's theories and methods in the education field" (p. 1185). This general definition implies that, as Yang explained, 'education' can be considered a field of business and is within the same dimension as 'automobile' or 'sports' in 'automobile marketing' or 'sports marketing.' Education marketing runs through a process involving factors similar to marketing other types of services. Camilleri (2019) demonstrated that this particular type of marketing could be seen and studied through a simple SWOT analysis (strengths, weaknesses, opportunities, and threats). This study aims to further position education marketing deep within the context of business strategies and planning: to question whether it can adapt to a significant change in the economic landscape.

\subsection{Marketing Mix of HEls}

Nonthapot and Thomya (2020) synthesized the 7P elements of the marketing mix as product, price, place, promotion, people, physical evidence, and process. This study utilizes this 7P marketing mix as the primary measurement of how far HEls can stretch their marketing strategies by altering their marketing mix's elements. In the context of marketing for HEls, as broken down by Tahir et al. (2017), the marketing mix would include:

1. Product (program): undergraduate, graduate, and postgraduate programs;

2. Price: fee levels, discounts, scholarships, and accommodations;

3. Promotion: advertising, publicity, and education expos;

4. Place: location of HEl and ease of access;

5. People: faculty, staff members, and students;

6. Process: teaching-learning activities, evaluation processes, admissions and staff recruitment activities; and 
7. Physical evidence (physical facilities): buildings, classrooms, libraries, laboratories, etc. (pp. 181-182)

\subsection{The adaptability of Marketing Mix during the COVID-19 pandemic}

Research by Dušek and Sagapova (2020) demonstrates how the marketing mix of one specific industry should change as customers' demands change during the COVID-19 pandemic. Dušek and Sagapova recommended that, based on a survey conducted towards Czech tourists, accommodation facilities in the Czech Republic should expand on the products they offer in response to the more recent trends that would see tourists preferring local travels less crowded tourist spots.

As demonstrated by the research mentioned above, the COVID-19 pandemic can significantly drive changes in the marketing efforts of an entire industry. On the other hand, this study fills a similar gap in the discussion of marketing activities amidst the pandemic while shifting the focus solely towards the higher education sector. Marketing for HEls as a discussion is a relatively new discursive territory. It is still debatable whether students can be considered 'customers' (Durkin, 2016), and this perspective could hinder HEls from acting the same way as entirely for-profit enterprises do.

\subsection{Parents' Position within Private HEls}

In the context of private HEls, it is safe to say that parents take a similar approach towards their children's education as they would in the school-parent dynamic in private schools. As stated by Chubb and Moe (1988), private schools have complete control over their goals, standards, and methods, which "may reflect the values of owners or patrons" $(p .1,067)$. Also, in the same light, in private schools, Chubb and Moe explicitly stated that students and parents "occupy a much more central position" (p. 1,068). The implication to this view is that parents can demand what methods private schools employ in their activities. However, before parents go into making demands for changes, it is worth noting that parents would first also go over the process of choosing an excellent school for their children based on "rational calculations of cost, benefits, and probabilities of success of options" (Bosetti \& Pyryt, 2007, p. 92). This study employs the same understanding of parents' roles in private schools to see the effects of their demands towards the changes in HEls' marketing mix during the pandemic.

\section{METHODOLOGY}

This research employed a deep narrative analysis which required in-depth interviews with actors involved in activities related to the sales and marketing of the HEls, which they are a part of. Five interviews were conducted through Google Meet, Zoom, and face-to-face meetings (all arranged according to the convenience of each informant), all in March 2021, with representatives from five different HEls located in four different cities: Jakarta (2), Bekasi (1), Bandung (1), and Surabaya (1). The informants interviewed are members of their HEls' 
marketing team, and by the time of the interviews, they had experienced selling their products both before and during the COVID-19 pandemic. All interviews were recorded (including one conducted in person), transcribed, and then coded based on two basic categories: what the informants thought changed and did not change from their marketing mix after the pandemic first began. From there, the author was able to determine the alterations made towards these HEls' marketing mix and parents' perspectives towards what they could and what they could not demand from HEls during the COVID-19 pandemic.

\section{RESULTS}

This results section is divided into five smaller sections, and each section presents findings from each of the five interviews. Excerpts from interview transcriptions had been translated from Bahasa Indonesia to English before being included in this chapter. The five sections are presented sequentially based on how interviews were conducted before the next ones. For confidentiality reasons, the names of both the HEls and the informants are undisclosed. The details of the HEls and the informants are as explained in Table 1.

Table 1. Details of interviews

\begin{tabular}{|c|c|c|}
\hline No. & Name of HEl & Details on informant (s) \\
\hline 1 & HEI 1 (campus location: Jakarta) & $\begin{array}{l}\text { Informant 1A (Head of Master of Management } \\
\text { Recruitment) } \\
\text { Informant 1B (Student Recruitment Staff Member \& PA to } \\
\text { Marketing Director) }\end{array}$ \\
\hline 2 & HEI 2 (campus location: Jakarta) & Informant 2 (Marketing Executive) \\
\hline 3 & HEI 3 (campus location: Bandung) & Informant 3 (Head of Interactive Marketing) \\
\hline 4 & $\begin{array}{l}\text { HEI } 4 \text { (campus location: } \\
\text { Surabaya) }\end{array}$ & Informant 4 (Marketing Staff Member) \\
\hline 5 & HEI 5 (campus location: Bekasi) & $\begin{array}{l}\text { Informant } 5 \text { (Marketing Staff Member for Jabodetabek } \\
\text { Area) }\end{array}$ \\
\hline
\end{tabular}

\subsection{HEI 1}

The first interview was conducted with two representatives from $\mathrm{HEI} 1$, located in Jakarta.

HEI 1 comprises two faculties/schools: Faculty of Management and Faculty of Creative Industries. This particular interview was Informant lA (Head of Master of Management Recruitment) and Informant 1B (Student Recruitment Staff Member \& PA to Marketing Director). As for the first five interviews, the questions were exploratory and relatively broad. The answers obtained from this interview were used as the basis of deeper inquiries during the following four interviews.

The first finding from the interview that the author would like to highlight is that parents had not had any demands or complaints regarding the learning process, which was moved 
to online platforms due to COVID-19 restrictions. When asked about whether the marketing team would communicate the changes in the learning process, Informant 1 A stated:

Since the pandemic has been going on since February or March, parents have been aware (of the changes in the learning process). However, there are still (parents) who would ask whether (the classes) would be held online or offline. (Informant 1A)

In general, parents' questions regarding learning during the pandemic would revolve around when face-to-face classes will resume and what facilities students could get to support their online learning. Parents' decision to whether or not to send their children to study at HEI 1 was said not to be affected by the switch to online learning as parents had already understood the changes that had to be made during the COVID-19 pandemic.

The finding that shows the difference in HEI 1 marketing activities during the COVID-19 pandemic is the campus's adjustments in reaction to the demands regarding payments. Regarding parents' questions that were asked only during the pandemic, Informant 1 A stated that parents would ask whether they still need to pay full tuition even when their children could not go to campus. Informant $1 \mathrm{~B}$ then continued to explain how parents would request financial aid:

(Parents would ask the campus) to increase the amount of scholarship given. So, if they have already been given a certain amount of scholarship (for their child), but (they would say) they need more scholarship. Alternatively, they would ask for financial aid more discounts. (Informant 1B)

With all that being said, HEl 1 still had not developed a rigid system of special payment arrangements for scholarships or discounts during the pandemic. Informant 1B explained:

It depends on what these parents request. We would usually inform the finance department (regarding a request made by a parent). If finance approves and the request makes sense, then it is done. (Informant 1B)

As with how marketing activities had been conducted during the pandemic, HEI 1 had been unable to do school visits. All marketing presentations had been done online through zoom. However, Informant 1A stated that this had resulted in more flexibility towards how HEI 1 's marketing team had approached their activities. Informant 1B explained that the entrance test usually done on campus on Sundays had been conducted online instead.

\subsection{HEI 2}

The second interview was conducted with Informant 2, a Marketing Executive from HEI 2, located in Jakarta. HEI 2 comprises two faculties/schools: the Faculty of Technology and 
Design and the Faculty of Social Science and Humanities. This interview was conducted using more or less the same questions but with one focus: do parents demand more scholarships/discounts/financial aid? The first interview inspired this added focus with HEl 1. It was intended to help the author determine whether the demand for financial aid during the COVID-19 pandemic also played a significant role in altering HEl 2's marketing mix.

The interview started with a simple question of "what is different about the marketing efforts of HEl 2 during the pandemic?". Informant 2 answered that there had been no significant difference generally as marketing activities are usually the same every year. However, these marketing activities had shifted to online ones where everything moved to Zoom and Google Meet: instead of doing school visits and organizing campus events, HEl 2 had been doing online marketing presentations, online scholarship info sessions, and virtual campus tours. Despite a decline in sales at the beginning of the pandemic, everything had gotten to its normal state pretty early on, with some Marketing Executives already reaching $50 \%$ of the annual sales target early at launch.

An exciting finding came after Informant 2 was asked regarding "what questions have parents begun to start asking since the beginning of the pandemic?". Informant 2 explained that, since campus promotional events had been done entirely online, HEI 2 marketing team had been making the extra effort to make sure parents could accompany their children during info sessions. It was due to some parents thinking that the information provided could be fraudulent. Informant 2 then remarked on payment installments, which he said that parents would now always ask. As planned, the author probed further on this subject. Informant 2 then further explained:

They (parents) would ask whether they should pay everything now (forward) or after (their children) finish their studies. Alternatively, (parents would also ask) whether there are other methods of installments. We do not know whether their families are affected economically during this pandemic. So, parents would ask for a longer time for (their) installment tenor (Informant 2).

The author then proceeded to ask regarding how the campus would handle these requests to which Informant 2 responded:

Because we have back-office and scholarship teams, they have prepared a method (for installments). So, first, when we inform (parents) about the scholarship (that their children get) and how the payment works, we inform them about the general method of installments. However, if parents feel they need more (scholarship/discount) or they need to be given a longer tenor, the scholarship team already has a policy (which enables them) to give the parents that (unique) tenor. (Informant 2) 
Before the pandemic, Informant 2 added, the nature of these 'special' tenors needed to be discussed first: no particular policy on this whatsoever which would allow parents to acquire financial aid instantly by request.

Besides a new policy on payment installments, HEl 2 also provided new scholarship opportunities, which the campus started to offer during the pandemic. A program had been established to enable first-year students not to have to pay any entry tuition fees. On top of that, these students could also get a partial to $100 \%$ discount on their semesterly tuition.

Informant 2 highlighted that changes in the product that HEI 2 marketed only went as far as adding different financial aids. If there were any, it would only be the free mobile internet plan that the campus distributed to students to help them with their online study, but this depended on the only learning needs of each program of study. Nonetheless, Informant 2 stated that this was also communicated to potential HEl 2 parents.

\subsection{HEI 3}

The third interview conducted was with Informant 3, the Head of Interactive Marketing at HEI 3, located in Bandung. HEI 3 is a Catholic HEl that comprises seven faculties/schools: economics, social and political sciences, IT and sciences, industrial technology, engineering, law, and philosophy. The questions and focuses of the interviews after the second one had been made consistent, making the third, fourth, and fifth interviews based on the HEl 2 (second) interview.

Early on during the interview, the author asked Informant 3 whether there had been shifts in parents' concerns/questions during campus info sessions conducted by HEl 3's marketing team specifically; the author asked regarding parents' concerns on the shift in the learning methods caused by the pandemic. Informant 3 responded with a straightforward answer:

In regards to learning methods, there have not been that many changes. (I) mean, it is still the same. However, there have been many questions regarding the technicalities of registration (for admission), selection, (and) payment. Those are the things that have changed a lot (regarding questions) (Informant 3).

Informant 3 then elaborated on how these three topics had been asked frequently by parents (admission registration, entrance selection, and payments). Firstly, there would be two options available for registration and selection before the pandemic: on-site and online. The pandemic had forced the former not to be an option, thus resulting in the marketing team conducting everything online. It posed a problem that saw parents who had low proficiency in digital technology needing more close guidance during both registration and the entrance test.

Secondly, in regards to payments, Informant 3 stated two main changes in financing methods policy at HEl 3: a higher scholarship quota for prospective students and the newlyallowed installment payments. HEI 3 provided different scholarships to students even before 
the pandemic started. However, during the pandemic, a new category of scholarship was provided where the requirements were loosened as opposed to other scholarships offered at HEI 3; it would usually take students to prepare every single required document to be able to apply for a scholarship, for this aptly-named Financial Aid Scholarship (Beasiswa Bantuan Ekonomi) the requirements had been loosened to just school recommendations or recommendations from a local public administration. As for payments, HEl 3 has since allowed parents to request installment payments.

As for other changes that were made by HEI 3, there were only a few that could be named. First, the campus had to increase its server size to accommodate a more massive online entrance test. The marketing team would also need to communicate HEl 3's more online approach to learning which utilizes a web-based learning platform that the campus had established. Informant 3 added that the campus had developed and used said online learning platform before the pandemic.

HEl 3's marketing activities had been done primarily online during the pandemic. Webinars and Zoom workshops had been heavily utilized instead of education expos. School visits had been mostly halted except for a few occasions when the marketing team visited some local Bandung schools to meet teachers.

\subsection{HEI 4}

The fourth interview was conducted with Informant 4, a Marketing Staff Member at HEl 4, located in Surabaya. HEI 4 is a culinary school that offers a 3-year advanced diploma culinary program and a 1-year certification gourmet program. HEl 4 was the most specialized school amongst the five involved in this research.

The interview began with a discussion on whether there had been questions from parents regarding the shift in the learning method. Informant 4 stated that questions about the learning process during the pandemic from both parents and school counselors (private HEls in Indonesia would organize promotional events at schools through counselors as their gatekeepers). Informant 4 explained that at HEl 4 , their learning would usually focus on $30 \%$ theories and $70 \%$ practical skills training. During the pandemic, lessons on theories were done online, and cooking classes were done fully offline on campus. Around $95 \%$ of the parents allowed their children to come to campus for these offline sessions, while the rest did not. For these students who were not allowed to come to campus by their parents, HEl 4 would ask them to keep the receipt of all the raw materials they had bought for reimbursement (the campus typically provides raw materials for cooking classes).

According to Informant 4 , only 1 or 2 potential parents had asked about a discount during the pandemic. As students could still get access to all facilities (even those who insisted on doing their cooking classes at home were given reimbursement for raw materials), HEl 4 did not provide potential students with any discount. The discount was only given to those 
admitted during the first registration batch, which would generally be the case before the pandemic. The only financial aid provided during the pandemic was a new policy on installment payments. During the pandemic, parents could request a longer tenor. The tuition fee could usually be paid in 3 to 4 installments; during the pandemic, it could be extended to 12 installments (1-year tenor). However, Informant 4 stated that there had only been 5 to 10 parents who requested a longer tenor.

HEI 4's marketing activities had been done online during the pandemic. The campus would generally rely on education fairs, cooking demonstrations, and events organized for school counselors. However, instead of the strategies mentioned earlier, the pandemic had forced them to settle with online presentations. That being said, Informant 4, the campus, would eventually combine old strategies with online marketing activities once the pandemic ends.

\subsection{HEI 5}

The last interview was with Informant 5, a Marketing Staff Member at HEI 5, located in Bekasi. The campus comprises four schools/faculties: business, engineering, computer science, and humanities. The interview began with the usual question of whether parents had been asking about the shift in learning methods since the start of the pandemic. Informant 5 stated that there had been quite a lot of questions on that topic. The marketing team would explain to these parents that the campus had an e-learning platform that had always been used even before the pandemic: it was not that the campus had to develop a unique online platform for the pandemic, but the marketing team would use this already created platform and explain it the parents as one of the main ways online classes were conducted. While this platform was only used as a medium to upload materials, online synchronous classes would still be conducted through Zoom or Google Meet.

Informant 5 stated that there had been no special scholarships made for during the pandemic in regards to payments. However, HEI 5 had established a collaboration with thirdparty financing platforms, enabling parents to pay their children's tuition in installments. These platforms had been certified by OJK (Otoritas Jasa Keuangan/Financial Services Authority). They could help parents by paying off their children's tuition first to HEI 5 as a loan that parents need to repay in installments. This payment method was new to HEI 5 as a way to help potential parents during the pandemic and had been offered by the marketing department to parents as a solution to their financing problems. Before this, HEl 5 only had one installment scheme where parents/students would need to fulfill the campus's requirements: the scheme would be determined by the HEl 5's finance department and parents' financial ability (and that would only cover for first year's entrance fees).

Most marketing endeavors at HEl 5 had been conducted online through Zoom events and webinars. Parents who had inquiries could still visit $\mathrm{HEl} 5$. However, inquiries were primarily 
made through calls or text messages (since some of the parents/potential students interested in HEl 5 lived outside the city). The marketing team had also been able to visit some schools outside the COVID-19 'red zones' to meet teachers, but they would need to make appointments first as these teachers would not always be at school. The way the marketing team would meet teachers would mainly be through webinars which were organized primarily for teachers.

\section{DISCUSSION}

The results above have significant implications on the general discussion of education marketing: the changes found in these HEls' marketing mix above further cement the notion that there is a producer-consumer relationship between HEls and students/parents. As demonstrated in research by Dušek and Sagapova (2020) on the tourism industry, consumers' demands during the COVID-19 pandemic could change the marketing strategies of a whole industry, and this research on HEls in Indonesia also demonstrates how the higher education industry could experience changes in its marketing strategies when there are changes in demands by consumers. However, with HEls, it is not that simple to pinpoint the drivers of the changes made in the industry's marketing endeavors.

Based on the 7P HEl marketing mix formulated by Tahir et al. (2017), seven essential elements make up the entire set of one HEl's marketing strategies: product, price, promotion, place, people, process, and physical evidence. The findings laid out in the results section show that only three of the seven P's were affected by the pandemic: price, promotion, and process. The changes can be broken down as follows:

1. Price: all five HEls had to create a new scholarship/discount scheme and/or a new payment system to accommodate parents who were having financial problems due to the pandemic;

2. Promotion: all five HEls had to settle with mostly remote marketing strategies, which utilized online communication/meeting platforms; and

3. Process: all HEls, except for HEl 4, had to settle with online classes (and HEls 1 and 3 admitted to conducting their entrance tests online during the pandemic).

Out of the three elements of the marketing mix that were affected, price is the only one that was a byproduct of parents' demands. The shift in promotion and classes/tests to online sessions is, on the other hand, a result of these HEls' responses towards the country's COVID-19 restrictions and concerns. This research found that the COVID-19 pandemic did not drive consumers to demand changes in products in the higher education industry, unlike what was found through the research on the tourism industry in the Czech Republic by Dušek and Sagapova (2020). 
As Chubb and Moe (1988) explained, parents play a more central role in private schools. In this case, private schools would have goals, standards, and methods affected by their patrons/parents. However, in the case of private HEls in Indonesia, that is certainly not the case. When choosing the best school for their children, parents would go through these rational calculations of different factors (Bosetti \& Pyryt, 2007), and what was found through this research is that parents would just stop at that calculative process rather than making demands based on how the pandemic had developed and affected them. The only demand they made was for HEls to understand their financial situation and help them get their children to start their studies amidst the pandemic.

\section{CONCLUSION}

This research is another proof that education marketing is a legitimate discursive vehicle in marketing research. The findings above have demonstrated that the higher education industry can adjust amidst an abruptly changing economic landscape, albeit with its different results due to the particularity of its producer-consumer relationship. However, this conclusion poses more questions for further research: do these findings speak for the entirety of the global higher education industry, or are they only valid for Indonesia? There are more phenomena to study out of marketing strategies in the higher education industry within many contexts. The author wishes that it does not end at the cultural relativity amongst different demographics of consumers. The producer-consumer relationship in the education industry (not just in higher education settings) in general needs to be explored further in its relation to education marketing and/or sales.

As for limitations, this research could have covered more of the 'physical evidence' element of the 7P marketing mix through individual observations in the five chosen HEls. By observing how the physical facilities in each of the HEls had been used during the pandemic, the author could have analyzed the shift in the utilization of these facilities, which would enable more conclusions to be drawn on the marketing as mentioned above mix element. Ironically, this limitation was also a byproduct of the current COVID-19 pandemic, which prevented the author from doing campus visits.

\section{REFERENCES}

Bapat, G. S., \& Gankar, S. S. (2019). Students recruitment strategies at higher educational institutes: A new world perspective - A review of the literature on higher education marketing. International Journal of Advanced Research, Ideas, and Innovations in Technology, 5(3), 1860-1864.

Bosetti, L., \& Pyryt, M. C. (2007). Parental motivation in school choice: Seeking the competitive edge. Journal of School Choice, 1 (4), 89-108. 
Camilleri, M. A. (2019). Higher education marketing: Opportunities and challenges in the digital era. Academia, 2019(16-17), 4-28.

Chubb, J. E., \& Moe, T. M. (1988). Politics, markets, and the organization of schools.

Durkin, M., Howcroft, B., \& Fairless, C. (2016). Product development in higher education marketing. International Journal of Educational Management, 30 (3), 354-369.

Dušek, R., \& Sagapova, N. (2021, January 13). Effect of the COVID-19 global pandemic on tourists' preferences and marketing mix of accommodation facilities - a case study from the Czech Republic. SHS Web of Conferences. https://www.shsconferences.org/articles/shsconf/abs/2021/03/shsconf_glob20_01009/shsconf_glob20 01009.html

Hutauruk, M. R. (2020). Keterterapan bauran pemasaran 4C pada keputusan konsumen untuk memilih kafe outdoor yang dimoderasi oleh perilaku konsumen dalam situasi pandemi covid-19. Jurnal Riset Inossa, 2(2), 80-91.

Jandrić, P. (2020b). Postdigital research in the time of Covid-19. Postdigital Science and Education, 2(2), 233-238. https://doi.org/10.1007/s42438-020-00113-8

Jarad, G. A. (2020). Application of the 4Cs marketing mix in the digital environment. International Journal of Psychological Rehabilitation, 24(10), 2113-2122.

Maniu, I., \& Maniu, G. C. (2014). Educational marketing: Factors influencing the selection of a university. SEA - Practical Application of Science, 3(5), 37-42.

Nonthapot, S., \& Thomya, W. (2020). The effect of the marketing mix on the demand of Thai and foreign tourists. Management Science Letters, 10(2020), 2437-2446. doi: $10.5267 / \mathrm{j} . \mathrm{msl} .2020 .4 .006$

Tahir, A. G., Rizvi, S. A. A., Khan, M. B., \& Ahmad, F. (2017). Keys of educational marketing. Journal of Applied Environmental and Biological Sciences, 7(1), 180-187.

The American Political Science Review, 82 (4), 1065-1087.

Yang, X. (2016). Education marketing research. Theoretical Economics Letters, 2016(6), 1180 1185. http://dx.doi.org/10.4236/tel.2016.65111 